\title{
Pengaruh Persentase Enzim Papain dan Bawang Putih pada Rendemen dan Kualitas VCO (Virgin Coconut Oil)
}

\section{(Effects of Papain Enzyme and Garlic Percentage on the Rendement and Quality of VCO [Virgin Coconut Oil])}

\author{
Munir Putro Prayugo ${ }^{1)^{*}}$, Ersan $^{2)}$, Febrina Delvitasari ${ }^{3)}$ \\ 1) Program Studi Produksi dan Manajemen Industri Perkebunan Politeknik Negeri Lampung dan \\ 2) Jurusan Budidaya Tanaman Perkebunan Politeknik Negeri Lampung, Jl. Soekarno-Hatta No. 10 \\ Rajabasa, Bandar Lampung, 35144, Telp.: (0721) 703995, Fax.: (0721) 787309 \\ E-mail: munirprayugo@gmail.com
}

\begin{abstract}
$V C O$ is an oil produced from coconuts that are treated with no heating, one of them using papain enzyme. Vegetable oil is a compound that is easily hydrolyzed and oxidized to make the quality of oil decline. Garlic is a natural antioxidant that can inhibit the oxidation process. Therefore, a study was conducted to determine the effect of papain and garlic enzymes on the rendement and storage duration of VCO. This study used a factorial randomized block design with the first factor was percentage of papain enzyme $10 \%$, $0,15 \%, 0,20 \%$, and $0,25 \%$ and the second factor was percentage of garlic $(0 \%, 0,5 \%$, and $1 \%)$ with 3 replications. The data of the research were analyzed by variance, followed by LSD test at 5\% level. The results showed that the highest VCO rendement was obtained from the treatment of 0,25\% papain enzyme. One percent (1\%) garlic can maintain the quality of water content, FFA, density, and color of VCO at 3 months storage duration, except aroma. The combination of papain and garlic enzymes resulted in negative effect on rendement and cannot maintain VCO quality at 3 months storage duration.
\end{abstract}

Keywords: enzyme papain, garlic, VCO storage

DOI: http://dx.doi.org/10.25181/jaip.v6i2.817

Diterima: 23 April 2018 / Disetujui: 10 Oktober 2018 / Diterbitkan: 29 Oktober 2018

\section{PENDAHULUAN}

Virgin Cococnut Oil (VCO) adalah minyak yang dihasilkan dari buah kelapa segar yang dalam pengolahannya menggunakan panas rendah atau tidak menggunakan panas sama sekali (Soekardi, 2012). VCO banyak digunakan dalam berbagai bidang industri, khususnya bidang kesehatan, karena mempunyai banyak manfaat. Produksi VCO di Indonesia saat ini masih jauh tertinggal jika dibandingkan dengan negara Filipina, Thailand, India, dan Srilanka. Nilai ekspor VCO Indonesia pada tahun 2015 mengalami penurunan sebesar 7,73\% dari tahun sebelumnya (Marjoko, 2015).

Penurunan nilai ekspor tersebut diduga disebabkan oleh kurangnya pengetahuan mengenai pengolahan VCO yang baik serta sarana produksi yang minim untuk produksi VCO yang bekualitas. Penurunan kualitas VCO dapat terjadi ketika pengolahan dan selama penyimpanan. 
Kualitas VCO akan menurun jika dalam pengolahannya menggunakan suhu di atas $60^{\circ} \mathrm{C}$, sedangkan ketika penyimpanan pada suhu yang tinggi dapat mempercepat proses hidrolisis dan oksidasi sehingga sifat fisikokimia minyak menurun (Winarti et al., 2007). untuk menjaga kualitas minyak kelapa, salah satunya yaitu dengan pengolahan tanpa pemanasan. Pengolahan VCO saat ini sudah banyak dikembangkan, seperti pengolahan VCO secara enzimatis. Pengolahan VCO secara enzimatis ini menggunakan enzim golongan protease yang merupakan enzim pengurai protein. Salah satu jenis enzim protease ini adalah papain. Pengolahan dengan metode ini tidak menggunakan panas, sehingga kualitas minyak yang dihasilkan dapat dijaga dari kerusakan karena suhu.

Bawang putih merupakan bahan yang tinggi akan antioksidan sehingga berpotensi untuk dapat digunakan dalam pengolahan VCO. Kandungan antioksidan berupa senyawa flavonoid pada bawang putih dapat menghambat proses oksidasi (Susilowati \& Harningsih, 2015). Selain itu senyawa alliin pada bawang putih mampu mengikat air, sehingga kandungan air pada VCO, serta senyawa allisin yang mempunyai sifat anti-bakteri dan mikro-organisme dapat menghabat proses pembentukan ALB (Widowati, 2006; Susilowati \& Harningsih, 2015).

Berdasarkan uraian tersebut, maka dilakukan penelitian untuk mendapatkan persentase penambahan enzim papain yang tepat untuk menghasilkan rendemen VCO tertinggi, mendapatkan persentase penambahan bawang putih yang tepat untuk mempertahankan kualitas VCO pada 3 bulan simpan, dan melihat pengaruh persentase penambahan enzim papain dan bawang putih pada rendemen dan kualitas VCO pada 3 bulan simpan.

\section{METODE PENELITIAN}

Penelitian dilaksanakan di Laboratorium Tanaman dan Laboratorium Teknologi Pangan Politeknik Negeri Lampung pada bulan Oktober 2016 sampai dengan Januari 2017. Bahan-bahan yang digunakan adalah buah kelapa tua yang diperoleh dari Desa Wiyono dan dipetik satu hari sebelum digunakan, enzim papain (Paya $\left.{ }^{\circledR}\right)$, bawang putih, $\mathrm{NaOH}$, alkohol, indikator fenolftalen dan akuades. Alat yang digunakan adalah golok, mesin parut, mesin peras kelapa parut, toples plastik, mixer, saringan teh, pipet, erlenmeyer, beaker glass, gelas ukur, spatula, $\mathrm{pH}$ meter, tabung suntik, labu ukur, oven, cawan alumunium, desikator, timbangan duduk $10 \mathrm{~kg}$, neraca analitik, buret, kertas label, kertas saring dan alat tulis.

Penelitian ini menggunakan rancangan acak kelompok pola faktorial. Faktor pertama adalah pemberian enzim papain dengan 4 aras $(0,0 \% ; 0,15 \% ; 0,20 \%$, dan $0,25 \%)$ dan faktor kedua penambahan bawang putih dengan 3 aras $(0 \% ; 0,5 \%$ dan $0,1 \%)$, perlakuan diulang 3 kali sehingga terdapat 36 satuan percobaan. Variabel yang diamati adalah rendemen (\%), kadar air (\%) (SNI No 7381 : 2008), asam lemak bebas (ALB) (SNI No 7381 : 2008), berat jenis (Ketaren, 1986), serta uji organoleptik, warna dan aroma (skoring). Data hasil pengamatan dianalisis dengan sidik ragam, apabila terdapat perbedaan nyata dilanjutkan dengan uji BNT pada tingkat kepercayaan $95 \%$.

114 Jurnal AIP Volume 6 No. 2 | Oktober 2018: 113-123 


\section{HASIL DAN PEMBAHASAN}

\section{Rendemen}

Pemberian enzim papain dan penambahan bawang putih berpengaruh nyata terhadap rendemen VCO. Nilai rerata interaksi dan pengaruh tunggal perlakuan persentase penambahan enzim papain dan bawang putih pada rendemen VCO dapat dilihat pada Tabel 1.

Tabel 1. Nilai rata-rata rendemen VCO berdasarkan uji BNT

\begin{tabular}{ccccc}
\hline Persentase enzim & \multicolumn{3}{c}{ Persentase bawang putih } & \multirow{2}{*}{ Rerata enzim papain } \\
\cline { 2 - 4 } papain & $0 \%$ & $0,5 \%$ & $1,0 \%$ & \\
\hline $0 \%$ & $18,5916^{\mathrm{b}}$ & $18,1475^{\mathrm{b}}$ & $15,7363^{\mathrm{a}}$ & $17,4918^{\mathrm{o}}$ \\
$0,15 \%$ & $22,2084^{\mathrm{d}}$ & $20,9394^{\mathrm{c}}$ & $20,5587^{\mathrm{c}}$ & $21,2355^{\mathrm{p}}$ \\
$0,2 \%$ & $25,0638^{\mathrm{e}}$ & $21,0028^{\mathrm{cd}}$ & $19,7972^{\mathrm{b}}$ & $21,9546^{\mathrm{p}}$ \\
$0,25 \%$ & $26,2060^{\mathrm{e}}$ & $22,2084^{\mathrm{d}}$ & $21,5105^{\mathrm{d}}$ & $23,3083^{\mathrm{q}}$ \\
\hline Rerata bawang putih & $23,0175^{\mathrm{z}}$ & $20,5745^{\mathrm{y}}$ & $19,4007^{\mathrm{x}}$ & \\
\hline
\end{tabular}

Keterangan: Nilai rata-rata yang diikuti huruf yang berbeda menunjukkan adanya perbedaan nyata menurut uji BNT pada taraf $\alpha=0,05$

Pemberian enzim papain dengan persentase yang semakin meningkat cenderung meningkatkan rendemen VCO, namun pemberian bawang putih dengan persentase yang semakin meningkat cenderung menurunkan rendemen VCO. Pemberian enzim papain pada persentase $0,15 \%$ dan $0,20 \%$ tidak menunjukan perbedaan rendemen. Hubungan antara persentase penambahan enzim papain dan bawang putih terhadap rendemen disajikan pada Gambar 1 berikut.

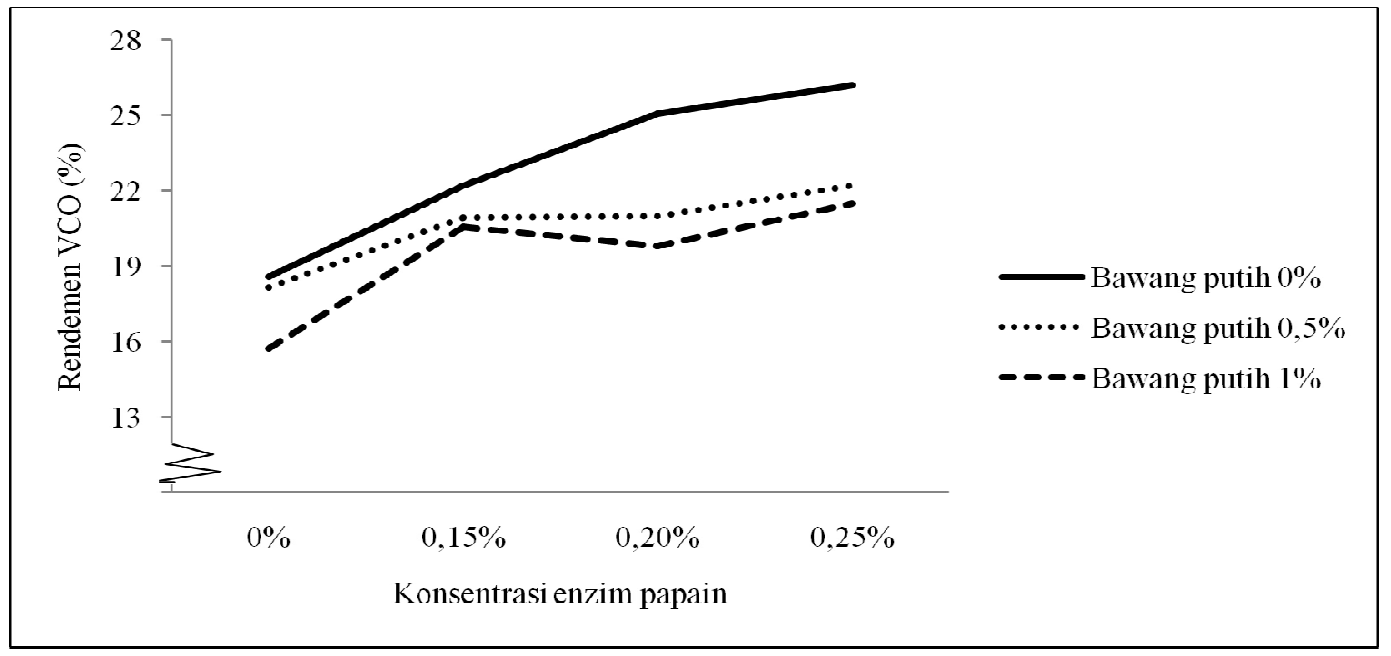

Gambar 1. Pengaruh enzim papain dan bawang putih pada rendemen VCO (\%) 
Pada Gambar 1 dapat dilihat bahwa terjadi kenaikan rendemen seiring kenaikan persentase enzim papain yang diberikan. Terjadi kenaikan rendemen sebesar $8,90 \%$ dari perlakuan persentase enzim papain $0,15 \%$, ke perlakuan enzim $0,25 \%$. Penambahan enzim papain dapat meningkatkan rendemen VCO karena enzim papain merupakan enzim proteolitik, yaitu enzim yang dapat mendenaturasi protein dengan proses hidrolisis. Persentase penambahan enzim papain yang diberikan pada santan kelapa pada pengolahan VCO membuat semakin banyak ikatan peptida dalam santan yang terurai. Hal ini didukung oleh penelitian Winarti et al. (2007), yang menyatakan bahwa semakin tinggi penambahan papain rendemen VCO yang dihasilkan semakin meningkat. Iskandar et al. (2015) menyatakan bahwa penambahan persentase enzim papain pada pengolahan VCO dapat meningkatkan rendemen VCO. Pada persentase penambahan bawang putih dalam pengolahan VCO justru mengalamai penurunan rendemen. Hal ini disebabkan bawang putih memiliki senyawa allisin yang mempunyai sifat dapat mengikat dan menurunkan lipid (Yuniastuti, 2006).

Terjadi pengaruh negatif antara enzim papain dan bawang putih dalam menghasilkan rendemen. Hal ini sesuai dengan penelitian Susilowati \& Harningsih (2015), yang menyatakan bahwa pengolahan VCO dengan penambahan bawang putih menghasilkan rendemen yang sedikit dibandingkan pengolahan tanpa penambahan bawang putih.

\section{Kadar Air}

Penambahan enzim papain bersama bawang putih tidak menyebabkan perbedaan kadar air VCO, akan tetapi pada faktor tunggal penambahan bawang putih menyebabkan perbedaan sangat nyata pada kadar air VCO. Rerata pengaruh tunggal perlakuan persentase penambahan enzim papain dan persentase bawang putih terhadap kadar air VCO dapat dilihat pada Tabel 2.

Tabel 2. Nilai rata-rata kadar air VCO berdasarkan uji BNT

\begin{tabular}{ccccc}
\hline \multirow{2}{*}{ Perlakuan } & & \multicolumn{3}{c}{ Pengamatan } \\
\cline { 3 - 5 } & & Bulan ke-1 (\%) & Bulan ke-3 (\%) & Peningkatan (\%) \\
\hline Enzim papain & $0 \%$ & $0,1494^{\circ}$ & $0,1629^{\circ}$ & 9,04 \\
& $0,15 \%$ & $0,1579^{\circ}$ & $0,1676^{\circ}$ & 6,14 \\
& $0,2 \%$ & $0,1545^{\circ}$ & $0,1631^{\circ}$ & 5,57 \\
& $0,25 \%$ & $0,1608^{\circ}$ & $0,1798^{\circ}$ & 11,82 \\
\hline Bawang putih & $0 \%$ & $0,1715^{\mathrm{y}}$ & $0,1925^{\mathrm{z}}$ & 12,24 \\
& $0,5 \%$ & $0.1524^{\mathrm{x}}$ & $0,1652^{\mathrm{y}}$ & 8,40 \\
& $1,0 \%$ & $0,1431^{\mathrm{x}}$ & $0,1474^{\mathrm{x}}$ & 3,00 \\
\hline
\end{tabular}

Keterangan: Nilai rata-rata yang diikuti huruf yang berbeda menunjukkan adanya perbedaan nyata menurut uji BNT pada taraf $\alpha=0,05$ 
Nilai rerata kadar air VCO pada perlakuan persentase enzim papain setelah 3 bulan masa simpan menunjukan nilai rerata antara 0,1629\% sampai dengan 0,1798\%. Kenaikan nilai kadar air tertinggi ditunjukkan pada persentase enzim papain 0,25\% yaitu sebesar 11,82\% sedangkan terendah pada persentase enzim papain $0,20 \%$ yang mengalami kenaikan kadar air sebesar 5,52\% akan tetapi nilai ini dianggap tidak berbeda nyata pada uji statistik BNT pada tingkat kepercayaan 95\%. Kenaikan kadar air ini terjadi karena selama masa penyimpanan minyak mengalami oksidasi pada asam lemak tidak jenuh yang terdapat pada minyak, dan reaksi oksidasi pada minyak ini menghasilkan gas $\mathrm{CO}_{2}$, asam-asam volatil, aldehid dan juga sejumlah air (Fadlana, 2006).

Pada perlakuan bawang putih, kenaikan terendah terjadi pada perlakuan bawang putih $1 \%$ dengan presentasi kenaikan 3\%, kemudian persentase 0,5\% dengan kenaikan sebesar 8,40\% dan kenaikan tertinggi pada perlakuan tanpa penambahan bawang putih dengan persentase kenaikan $12,24 \%$. Rendahnya presentasi kenaikan kadar air pada perlakuan penambahan bawang putih diduga disebabkan oleh senyawa innulin pada bawang putih. Rendahnya nilai kadar air pada VCO disebabkan bawang putih mengandung senyawa innulin yang memiliki sifat mampu mengikat air (Widowati, 2006).

\section{Asam Lemak Bebas (ALB)}

Penambahan enzim papain tidak menyebabkan perbedaan ALB, sedangkan penambahan bawang putih menyebabkan perbedaan sangat nyata pada ALB, akan tetapi tidak terjadi interkasi diantara keduanya. Rerata pengaruh tunggal perlakuan penambahan persentase enzim papain dan persentase bawang putih terhadap ALB VCO dapat dilihat pada Tabel 3.

Tabel 3. Nilai Rerata ALB VCO berdasarkan uji BNT

\begin{tabular}{rccc}
\hline \multirow{2}{*}{ Perlakuan } & \multicolumn{3}{c}{ Pengamatan } \\
\cline { 2 - 4 } & Bulan ke-1 $(\%)$ & Bulan ke-3 $(\%)$ & Peningkatan (\%) \\
\hline Enzim papain $0 \%$ & $0,1693^{\circ}$ & $0,2345^{\circ}$ & 38,51 \\
$0,15 \%$ & $0,1722^{\circ}$ & $0,2274^{\circ}$ & 32,06 \\
$0,2 \%$ & $0,1739^{\circ}$ & $0,2275^{\circ}$ & 30,82 \\
$0,25 \%$ & $0,1735^{\circ}$ & $0,2408^{\circ}$ & 38,78 \\
\hline Bawang putih $0 \%$ & $0,1815^{\mathrm{y}}$ & $0,2613^{\mathrm{z}}$ & 43,97 \\
$0,5 \%$ & $0,1699^{\mathrm{x}}$ & $0,2367^{\mathrm{y}}$ & 39,32 \\
$1,0 \%$ & $0,1654^{\mathrm{x}}$ & $0,1997^{\mathrm{x}}$ & 20,74
\end{tabular}

Keterangan: Nilai rata-rata yang diikuti huruf yang berbeda menunjukkan adanya perbedaan nyata menurut uji BNT pada taraf $\alpha=0,05$

Berdasarkan hasil pengukuran ALB pada pengamatan bulan ke-1 (Tabel 3), nilai ALB dari semua perlakuan berkisar antara $0,16 \%$ sampai dengan $0,18 \%$ yang berarti nilai ALB masih 
memenuhi standar yang ditetapkan oleh Badan Standarisasi Nasional (BSN) No.7381 tahun 2008 yang menghendaki ALB maksimal dalam VCO sebesar 0,2\%. Nilai ALB pada perlakuan enzim papain $0 \%$ sampai dengan $0,25 \%$ memiliki nilai yang tidak jauh berbeda. Berbeda dengan perlakuan pada persentase bawang putih. Pada perlakuan persentase bawang putih $0,5 \%$ dan $1 \%$ memiliki nilai ALB yang jauh berbeda dengan perlakuan kontrol. Rendahnya nilai ALB pada perlakuan persentase bawang putih $0,5 \%$ dan $1 \%$ diduga karena kandungan air yang terdapat pada VCO rendah sehingga proses hidrolisis berjalan lambat. Hal ini sesuai dengan pernyataan Iskandar c (2015) yang mengungkapkan bahwa salah satu penyebab tingginya nilai ALB adalah tingginya kadar air pada VCO karena proses hidrolisis terjadi apabila dalam VCO terdapat sejumlah molekul air yang cukup.

Pada pengamatan bulan ke-3 nilai rata-rata ALB VCO mengalami kenaikan. Nilai rata-rata ALB dari semua perlakuan berkisar antara 0,19\% sampai dengan $0,24 \%$. Kenaikan yang signifikan pada pengolahan VCO secara enzimatis ini diduga disebabkan oleh reaksi hidrolisis pada minyak. Hal ini didukung oleh Raharja \& Dwiyuni (2005), yang mengatakan bahwa asam lemak bebas dihasilkan melalui reaksi hidrolisis yang dapat disebabkan oleh sejumlah air, enzim lipase ataupun aktivitas mikroorganisme. Semakin tinggi kadar air dalam minyak dapat mengakibatkan asam lemak bebas juga tinggi.

Dari nilai rata-rata ALB setelah 3 bulan simpan hanya pada perlakuan persentase bawang putih $1 \%$ yang memiliki nilai ALB kurang dari 0,2\% yaitu 0,1997\%. Oleh karena itu, perlakuan persentase bawang putih 1\% dapat dikatakan mampu mempertahankan ALB setelah 3 bulan simpan. Rendahnya nilai ALB pada penambahan bawang putih $1 \%$ diduga disebabkan oleh rendahya kadar air, seperti pada pengamatan kadar air hanya terjadi kenaikan 3\% setelah 3 bulan simpan.

\section{Berat Jenis}

Penambahan enzim papain tidak menyebabkan perbedaan berat jenis VCO, sedangkan penambahan bawang putih menyebabkan perbedaan nyata pada berat jenis VCO, akan tetapi tidak terjadi interaksi diantara keduanya. Rerata pengaruh tunggal perlakuan penambahan persentase enzim papain dan persentase bawang putih dapat dilihat pada Tabel 4.

Berdasarkan hasil pengukuran berat jenis pada pengamatan bulan ke-1 nilai berat jenis dari semua perlakuan berkisar antara 0,8995\% sampai dengan 0,9041\% yang berarti nilai berat jenis masih memenuhi standar yang ditetapkan. Enzim papain tidak mempengaruhi berat jenis VCO, karena diduga peran enzim papain dalam pengolahan VCO hanya berfungsi sebagai pengurai protein pada emulsi santan. Hal ini didukung oleh penelitian Iskandar et al. (2015), yang menyatakan bahwa enzim papain tidak mempengaruhi berat jenis VCO pada pengolahan secara enzimatis. Pada perlakuan bawang putih nilai berat jenis VCO pada persentase $0,5 \%$ sebesar 0,89965 dan $1 \%$ sebesar 0,9027 dianggap berbeda nyata terhadap perlakuan tanpa penambahan 
bawang putih dengan nilai berat jenis $0,9041 \%$. rendahnya nilai berat jenis pada perlakuan penambahan bawang putih diduga disebabkan oleh kandungan innulin pada bawang putih yang dapat menyerap air. Pada saat proses pengolahan berlangsung innulin berperan dalam reaksi dan membuat kandungan air yang terikut pada minyak sedikit (Widowati, 2006).

Tabel 4. Nilai rerata berat jenis VCO berdasarkan uji BNT

\begin{tabular}{ccccc}
\hline \multirow{2}{*}{ Perlakuan } & \multicolumn{3}{c}{ Pengamatan } \\
\cline { 2 - 5 } & & Bulan ke-1 (g.ml $\left.{ }^{-1}\right)$ & Bulan ke-3 $\left(\mathrm{g} \cdot \mathrm{ml}^{-1}\right)$ & Peningkatan (\%) \\
\hline Enzim papain & $0 \%$ & $0,9037^{\circ}$ & $0,9201^{\circ}$ & 1,81 \\
& $0,15 \%$ & $0,9011^{\circ}$ & $0,9217^{\circ}$ & 2,29 \\
& $0,2 \%$ & $0,9013^{\mathrm{o}}$ & $0,9227^{\circ}$ & 2,37 \\
& $0,25 \%$ & $0,9022^{\circ}$ & $0,9221^{\circ}$ & 2,21 \\
\hline Bawang putih & $0 \%$ & $0,9041^{\mathrm{y}}$ & $0,9220^{\mathrm{x}}$ & 1,98 \\
& $0,5 \%$ & $0,8995^{\mathrm{x}}$ & $0,9211^{\mathrm{x}}$ & 2,40 \\
& $1,0 \%$ & $0,9027^{\mathrm{x}}$ & $0,9195^{\mathrm{x}}$ & 1,86
\end{tabular}

Keterangan: Nilai rata-rata yang diikuti huruf yang berbeda menunjukkan adanya perbedaan nyata menurut uji BNT pada taraf $\alpha=0,05$

Dari nilai rata-rata berat jenis pengamatan bulan ke-3 pada semua perlakuan nilainya mengalami kenaikan, kenaikan berkisar 1,81\%-2,37\%. Kenaikan nilai berat jenis ini diduga disebabkan oleh kenaikan kadar air pada minyak VCO. Hal ini sejalan dengan pendapat Fadlana (2006), yang mengungkapkan bahwa selama masa penyimpanan minyak mengalami oksidasi pada asam lemak tidak jenuh yang terdapat pada minyak, dan reaksi oksidasi pada minyak ini menghasilkan gas $\mathrm{CO}_{2}$, asam-asam volatil, aldehid, dan juga sejumlah air.

Nilai berat jenis pada perlakuan persentase enzim papain $0 \%$ lebih rendah bila dibandingkan dengan perlakuan persentase lainnya, akan tetapi nilai ini tidak memenuhi standar yang ditetapkan oleh APPC dan SNI. Perlakuan persentase penambahan bawang putih $1 \%$ menunjukan nilai yang lebih rendah dan masuk dalam standar APPC. Rendahnya nilai berat jenis pada perlakuan bawang putih $1 \%$ diduga karena senyawa flavonoid pada bawang putih menghambat proses oksidasi pada minyak. Hal ini didukung pernyataan dari Susilowati \& Harningsih (2015) yang mengungkapkan bahwa senyawa flavonoid pada bawang putih dapat menurunkan oksidasi.

\section{Warna}

Hasil uji sidik ragam pada perlakuan penambahan persentase enzim papain dan bawang putih tidak berbeda nyata pada warna VCO serta tidak terjadi interaksi diantara keduanya. Rerata pengaruh tunggal perlakuan persentase penambahan enzim papain dan persentase persentase Jurnal AIP Volume 6 No. 2 | Oktober 2018: 113-123 
bawang putih terhadap warna VCO dapat dilihat pada Tabel 5. Berdasarkan hasil pengukuran warna pada pengamatan bulan ke-1 skor warna berdasarkan penilaian panelis dari semua perlakuan berkisar antara 4,15 sampai dengan 4,19 yang berdasarkan kuisioner penilaian masih masuk dalam kategori jernih sehingga warna memenuhi standar yang ditetapkan oleh Badan Standardisasi Nasional (BSN) No.7381 tahun 2008 yang menghendaki warna VCO jernih. Kejernihan warna VCO diduga disebabkan oleh dominansi pigmen warna minyak asli VCO yang berwarna bening. Warna minyak disebabkan oleh pigmen yang merupakan fraksi non minyak (Iskandar et al., 2015). Warna minyak dan lemak ditentukan berdasarkan dari macam pigmennya (Winarno, 1992).

Tabel 5. Nilai rata-rata warna VCO berdasarkan uji BNT

\begin{tabular}{ccccc}
\hline \multirow{2}{*}{ Perlakuan } & & \multicolumn{3}{c}{ Pengamatan } \\
\cline { 3 - 5 } & & Bulan ke-1 & Bulan ke-3 & Penurunan (\%) \\
\hline Enzim papain & $0 \%$ & $4,1683^{\circ}$ & $3,7727^{\circ}$ & 9,5 \\
& $0,15 \%$ & $4,1544^{\circ}$ & $3,7266^{\circ}$ & 10,3 \\
& $0,2 \%$ & $4,1911^{\circ}$ & $3,7773^{\circ}$ & 9,9 \\
& $0,25 \%$ & $4,1666^{\circ}$ & $3,7822^{\circ}$ & 9,2 \\
\hline Bawang putih & $0 \%$ & $4,1637^{\mathrm{x}}$ & $3,7600^{\mathrm{x}}$ & 9,7 \\
& $0,5 \%$ & $4,1591^{\mathrm{x}}$ & $3,7636^{\mathrm{x}}$ & 9,5 \\
& $1,0 \%$ & $4,1875^{\mathrm{x}}$ & $3,7705^{\mathrm{x}}$ & 10,0
\end{tabular}

Keterangan: Nilai rata-rata yang diikuti huruf yang berbeda menunjukkan adanya perbedaan nyata menurut uji BNT pada taraf $\alpha=0,05$

Pada pengamatan bulan ke-3, rata-rata penilaian panelis terhadap warna VCO menurun berkisar antara 9,2\% - 10,3\%. Rata-rata skor yang diberikan panelis terhadap warna VCO dari semua perlakuan adalah 3,7 yang berdasarkan kuisioner kualitas VCO masih dalam kategori berwarna jernih. Penurunan skor panelis terhadap warna VCO diduga karena, seiring dengan terjadinya penurunan kualitas pada kadar air, ALB, dan berat jenis VCO selama 3 bulan penyimpanan. Selama penyimpanan, minyak akan terjadi perubahan warna dan rasa yang disertai dengan terbentuknya komponen komponen yang tidak diinginkan dan juga terjadi perubahan aroma (Ketaren, 1986; Five, 2004).

\section{Aroma}

Berdasarkan uji sidik ragam pada perlakuan persentase penambahan enzim papain dan bawang putih berbeda nyata terhadap kontrol, akan tetapi tidak terjadi interaksi antara keduanya. Rerata pengaruh tunggal perlakuan persentase penambahan enzim papain dan persentase penambahan bawang putih terhadap aroma VCO dapat dilihat pada Tabel 6. 
Berdasarkan Tabel 6 nilai panelis terhadap perlakuan 0\% enzim papain mempunyai penilaian tertinggi dibandingkan dengan perlakuan lainnya. Berdasarkan hal tersebut, VCO yang diberikan perlakuan penambahan enzim papain kurang disukai jika dibandingkan dengan kontrol. Sedangkan penilaian panelis terhadap penambahan bawang putih $0,5 \%$ dan $1 \%$ mempunyai skor 3,2 dan 3,1 . Penambahan bawang putih mempengaruhi aroma VCO diduga karena, kandungan allisin pada bawang putih yang memiliki kandungan sulfur membuat aroma khas bawang putih muncul. Susilowati \& Harningsih (2015) mengungkapkan kandungan sulfur pada bawang putih membuat aroma khas bawang putih.

Tabel 6. Nilai rata-rata aroma VCO berdasarkan uji BNT

\begin{tabular}{ccccc}
\hline \multirow{2}{*}{ Perlakuan } & & \multicolumn{3}{c}{ Pengamatan } \\
\cline { 2 - 5 } & & Rerata bulan ke-1 & Rerata bulan ke-3 & Perubahan (\%) \\
\hline Enzim papain & $0 \%$ & $4,0633^{\mathrm{p}}$ & $4,1060^{\mathrm{p}}$ & +1 \\
& $0,15 \%$ & $3,3609^{\circ}$ & $3,1385^{\circ}$ & -7 \\
& $0,2 \%$ & $3,2958^{\circ}$ & $3,1633^{\circ}$ & -4 \\
& $0,25 \%$ & $3,2959^{\circ}$ & $3,1444^{\circ}$ & -5 \\
\hline Bawang putih & $0 \%$ & $4,0375^{\mathrm{y}}$ & $4,1795^{\mathrm{y}}$ & +4 \\
& $0,5 \%$ & $3,2755^{\mathrm{x}}$ & $2,9878^{\mathrm{x}}$ & -9 \\
& $1,0 \%$ & $3,1990^{\mathrm{x}}$ & $2,9968^{\mathrm{x}}$ & -6
\end{tabular}

Keterangan: Nilai rata-rata yang diikuti huruf yang berbeda menunjukkan adanya perbedaan nyata menurut uji BNT pada taraf $\alpha=0,05$

Pada pengamatan bulan ke-3 rata-rata penilaian panelis terhadap aroma VCO yang diberikan perlakuan menurun, akan tetapi terdapat kenaikan skor terhadap aroma pada perlakuan tanpa persentase penambahan enzim papain dan bawang putih. Perlakuan tanpa menggunakan persentase enzim papain memiliki skor 4,1 atau naik sekitar $1 \%$ dari bulan sebelumnya, sedangkan pada perlakuan $0,15 \%$ sampai dengan $0,25 \%$ menunjukan adanya penurunan skor yang diberikan panelis sekitar $4 \%$ sampai dengan $7 \%$. Tidak adanya aktivitas enzim pada perlakuan $0 \%$ enzim papain dan 0\% bawang putih diduga menjadi penyebab bertahannya kualitas terhadap aroma. Selain itu, rendahnya nilai penurunan VCO disebabkan oleh kestabilan minyak VCO. Kandungan phitosterol dalam VCO yang tidak berwarna, tidak berbau, dan stabil serta berfungsi sebagai stabilizer dalam minyak (Ketaren 1986).

Pada persentase penambahan bawang putih $0,5 \%$ dan $1 \%$ terjadi penurunan skor yang diberikan panelis terhadap aroma VCO. Penurunan ini terjadi karena pada perlakuan penambahan bawang putih mempunyai aroma khas bawang putih yang menyengat. Aroma khas bawang putih yang menyengat pada minyak VCO diduga disebabkan oleh semakin banyaknya ikatan rangkap 
pada minyak VCO yang lepas dan berikatan dengan gugus sulfur akibat kerusakan minyak yang terjadi.

\section{KESIMPULAN}

Persentase enzim papain $0,25 \%$ memberikan hasil rendemen VCO tertinggi yaitu sebesar 23,51\%. Persentase bawang putih $1 \%$ dapat mempertahankan kadar air, ALB, berat jenis, dan warna VCO pada 3 bulan simpan, akan tetapi tidak untuk aroma. Kombinasi perlakuan enzim papain dan bawang putih menghasilkan pengaruh negatif terhadap rendemen dan tidak dapat mempertahankan kualitas VCO pada 3 bulan simpan.

\section{DAFTAR PUSTAKA}

Badan Standardisasi Nasional. (2008). Minyak Kelapa Virgin (VCO). Badan Standardisasi Nasional Indonesia. Jakarta.

Fadlana, M. H. (2006). Pengaruh Suhu Penyimpanan dan Cara Ekstraksi Virgin Coconut Oil (VCO) terhadap Mutu Minyak yang Dihasilkan Selama Penyimpanan. Unpublished undergraduate thesis, Institut Pertanian Bogor, Bogor.

Five, B. (2004). Coconut Oil Miracle. Jakarta: PT Buana Ilmu Populer.

Iskandar, A., Ersan, E., \& Edison, R. (2015). Pengaruh dosis enzim papain terhadap rendemen dan kualitas virgin coconut oil (VCO). Jurnal Agro Industri Perkebunan, 3(2), 82-93.

Ketaren, S. (1986). Pengantar Teknologi Minyak dan Lemak. Jakarta: UI Press.

Marjoko, G. (2015). Virgin coconut oil komoditas ekspor. Retrieved November 20, 2016, from www.rumahumkm.net/2015/08/vco-virgin-coconut-oil-komoditas-ekspor.html.

Raharja, S., \& Dwiyuni, M. (2008). Kajian sifat fisiko kimia ekstrak minyak kelapa murni (virgin coconut oil, VCO) yang dibuat dengan metode pembekuan krim santan. Jurnal Teknik Industri Pertambangan, 18(2), 71-78.

Soekardi, Y. (2012). Pemanfaatan dan Pengolahan Kelapa Menjadi Berbagai Bahan Makanan dan Obat Berbagai Penyakit. Bandung: Yrama Widya.

Susilowati, I. T., \& Harningsih, T. (2015). Penambahan bawang putih (Allium sativum) terhadap kualitas virgin coconut oil (VCO) sebagai minyak goreng. Jurnal Kesehatan Kusuma Husada, 6(2), 96-103.

Widowati, S. (2006). Dahlia bunganya indah, umbinya mengandung inulin. Sinar Tani edisi, 19-25.

Winarno, F.G. (1983). Enzim Pangan. Jakarta: PT Gramedia.

Winarti, S., \& Jariyah, P. Y. (2007). Proses pembuatan VCO (virgin coconut oil) secara enzimatis menggunakan papain kasar. J Teknol Pertan, 8(2), 136-41.

Yuniastuti, K. (2006). Ekstraksi dan Identifikasi Komponen Sulfida Pada Bawang Putih (Allium

122 Jurnal AIP Volume 6 No. 2 | Oktober 2018: 113-123 
sativum). Unpublished doctoral dissertation, Universitas Negeri Semarang, Semarang. 